\title{
PELATIHAN MEMBUAT BATIK TULIS MOTIF JAGUNG GUNA MENINGKATKAN LIFE SKILLS WARGA KEDIREN MAGETAN
}

\author{
Mayrina Eka Prasetyo Budi \\ Fakultas Ushuddin Adab dan Dakwah IAIN Ponorogo \\ e-mail:mayrinaeka@iainponorogo.ac.id
}

\begin{abstract}
ABSTRAK
Mayoritas warga Desa Kediren bermata pencaharian sebagai petani jagung. Selain bertani, terkadang masyarakat juga membuat batik sebagai mata pencaharian tambahan. Industri batik tulis Desa Kediren Kabupaten Magetan baru berjalan enam bulan. Industri batik tulis motif jagung sebagai ikon kebanggan Desa Kediren belum berjalan dengan baik dikarenakan keterbatasan sumber daya manusia yang memiliki kemampuan membuat batik. Tujuan pengabdian yang kami lakukan adalah meningkatkan life skills membuat batik tulis motif jagung bagi warga. Metode yang digunakan dalam pengabdian iniadalah Asset Based Communities Development (ABCD) yaitu melakukan pelatihan dengan praktik membuat batik tulis motif jagung bersama warga dengan fasilitator salah satu warga yang sudah lebih kompeten dalam membuat batik tulis motif jagung. Hasil dari pengabdian masyarakat menunjukkan meningkatnya kemampuan warga dalam membuat batik tulis motifjagung. Mereka lebih terampil dan batik yang dibasilkan lebih bagus dari sebelumnya.Jadi pelatiban ini penting guna meningkatkan life skills dalam membuat batik tulis motif jagung warga Desa Kediren Kabupaten Magetan.
\end{abstract}

Kata kunci: Pelatihan, Batik, Life Skills, Desa Kediren

\begin{abstract}
The majority of Kediren Village residents work as corn farmers. Apart from farming, sometimes people also make batik as an additional source of income. The batik industry in Kediren Village, Magetan Regency, has only been running for six months. The batik industry, with corn motifs as the proud icon of Kediren Village, has not been running well due to limited human resources who have the ability to make batiks. The goal of our dedication is to improve life skills by making batik with corn motifs for the residents. The method used in this service is Asset Based Communities Development $(A B C D)$, which is training by practicing making written batik with corn motifs together with the community with the facilitator, one of the residents who is more competent at making batik with corn motifs. The results of community service show the increasing ability of residents to make batik with a corn motif. They are more skilled and the batik they produce is better than before. So, this training is important in order to improve life skills in making written batik with corn motifs in Kediren Village, Magetan Regency.
\end{abstract}

Keywords: Training, Batik, Life skills, Kediren Village. 


\section{Indonesian Engagement Journal}

\section{Vol. 2 No. 1 Juni 2021}

\section{PENDAHULUAN}

Batik adalah kerajinan yang memiliki nilai seni tinggi dan telah menjadi bagian dari budaya Indonesia sejak lama. Batik sebuah karya bangsa yang menyimpan nilai luhur budaya bangsa masyarakat Indonesia.Sejak berabad-abad lalu batik sudah digunakan kaum wanita dan pria yang tetap lekat dalam kehidupan orang Jawa, Madura, dan Sumatra.Saat ini batik Indonesia telah diakui oleh bangsa-bangsa lain, bahkan tersebar di berbagai negara. ${ }^{1}$ Batik Indonesia oleh UNESCO telah ditetapkan sebagai Warisan Kemanusiaan untuk Budaya Lisan dan Nonbendawi (Masterpieces Of The Oral and Intangible Heritage of Humanity) sejak 2 Oktober 2009. ${ }^{2}$ Penetapan ini sangat membanggakan bagi masyarakat Indonesia, karena sudah ada pengakuan dari dunia internasional bahwa batik merupakan salah satu budaya milik Indonesia asli, dan pemerintah telah menjadikan tanggal 2 Oktober sebagai Hari Batik. ${ }^{3}$

Pengakuan batik dari UNESCO sebagai warisan dunia menjadikan permintaan batik makin bertambah. ${ }^{4}$ Pangsa pasar batik semakin tersebar luas. Ini menjadi kesempatan emas bagi wirausahawan yang bergerak di bidang industri batik. Apalagi pemerintah memberikan arahan agar para ASN menggunakan batik pada hari-hari tertentu, khususnya pada momentum peringatan Hari Batik Nasional. ${ }^{5}$ Masyarakat umum dari berbagai rentang usia (tua, muda, anak-anak) juga semakin bangga menggunakan batik dalam keseharian atau dalam berbagai acara. ${ }^{6}$ Batik adalah suatu gambar yang berpola, motif dan coraknya dibuat secara khusus dengan menggunakan tehnik tutup celup. Bahan yang dipakai untuk tehnik tutup yaitu malam dan alatnya

1 Kusrianto, A. Batik, Filosofi, dan Kegunaan (Yogyakarta: Penerbit Andi, 2014), 56.

2 Sari, I.P., dkk., "HKI pada Batik Tulis Indonesia (Studi Kasus Batik Tulis Tanjung Bumi, Madura" Jurnal Ekonomi Pendidikan dan Kewirausahaan Unesa (2018), 62.

3 Indrati, A., dkk., "Pengembangan Dokumentasi Elektronik Batik Jawa, Bali dan Madura Berbasis Web," laporan penelitian, Universitas Gunadarma, Jakarta (2011), 88.

4 Suliyanto Novandari, "Persepsi Generasi Muda Terhadap Profesi XVIII," Jurnal Pengabdian (2015), 135-144.

5 Nurainun, “Analisis Industri Batik di Indonesia. Fokus Ekonomi,” Jurnal Pengabdian (2008), (3), 124-135.

6 Utami, A.D., \& Triyono, R.A., "Pemanfaatan Blackberry Sebagai Sarana Komunikasi dan Penjualan Batik Online dengan Sistem Dropship di Batik Solo 85," Jurnal Speed Sentra Penelitian Engineering Dan Edukasi, 3 (3), 33-40. https://doi.org/10.3112/speed.v4i4.1099. 


\section{Indonesian Engagement Journal}

\section{Vol. 2 No. 1 Juni 2021}

adalah canting tulis, canting cap, kuas atau alat lainnya. Cara membuatnya dengan ditulis, dilukis atau dicap pada kain (mori, katun, teteron, sutera dan lain-lain). ${ }^{7}$

Variasi batik makin bertambah seiring dadanya pengakuan UNESCO. ${ }^{8}$ Terdapat tiga jenis batik berdasarkan cara membuatnya yaitu batik tulis, batik lukis, dan batik cap. ${ }^{9}$ Batik tulis adalah batik yang dibuat dengan memakai canting.Batik lukis adalah proses pembuatan batik dengan cara langsung melukis pada kain putih. Pembuatan kedua jenis batik ini memakan waktu sekitar 2-3 bulan. Batik cap adalah batik yang memiliki tekstur atau corak dibentuk dengan cap (biasanya terbuat dari tembaga). Proses pembuatan batik cap lebih cepat yaitu sekitar 2-3 hari. Saat ini mulai berkembang batik salon atau printing. Batik sablon atau printing adalah batik yang proses pembuatannya dicetak melalui proses sablon atau menggunakan mesin. Waktu pembuatan batik sablon lebih cepat karena biasanya industri massal. Dari ketiga jenis, kualitas batik tulis lebih bagus karena proses pembuatannya yang menggunakan canting, sehingga memiliki seni tersendiri yang unik, istimewa dan eksklusif. ${ }^{10}$

Industri batik sebagai warisan budaya banyak dikembangkan di daerah Jawa. Delapan puluh tujuh persen industri batik di Indonesia tersebar di Jawa Barat (38,42\%), Jawa Tengah (26,22\%), Daerah Istimewa Yogyakarta (19,52\%), Jawa Timur (2,66\%), Bnaten (0,23\%), dan Daerha Khusus Ibukota (DKI) Jakarata (0,05\%) adapaun di luar Pulau Jawa batik Provinsi Jambi menjadi yang terbanyak. ${ }^{11}$

Batik Jawa mempunyai motif yang berbeda beda. Adanya perbedaan motif batik dikarenakan bervariasinya lingkungan wilayah di mana batik dibuat. Motif batik bukan hanya sebuah gambar, akan tetapi mengandung makna tertentu.Batik Jawa banyak berkembang di daerah Solo, Yogyakarta, Pekalongan dan berbagai kota di Jawa termasuk di Kota Magetan. Kota Magetan menjadi salah satu pusat kerajinan kain batik tulis yang tidak kalah menariknya dengan wilayah lainnya.Kota Magetan

7 Wahono. Dkk., Gaya Ragam Hias Batik: Timjauan Makna dan Simbol (Semarang: Pemerintah Daerah Propinsi Jawa Tengah, Dinas Pendidikan dan Kebudayaan Museum Jawa Tengah "Ronggowarsito" 2004), 54.

8 Wulandari, Batik Nusantara Makna Filosofis, Cara Pembuatan dan Industri Batik (Yogyakarta: Andi OFFSET, 2011), 88.

9 Singgih, "Karakteristik Motif Batik Kendal Interpretasi dari Wilayah dan Letak Geografis," Jurnal Imajinasi (2016). 2.

10 Margaria, "Jenis-jenis batik menurut cara pembuatannya," http://margaria.co.id., akses 1 Oktober 2019

11 Siregar, A.P., dkk, "Upaya Pengembangan Industri Batik Di Indonesia: Dinamika Kerajinan dan Batik," Majalah Ilmiah Vol. 37 No.1, Juni (2020), 92. 


\section{Indonesian Engagement Journal}

Vol. 2 No. 1 Juni 2021

memiliki potensi pembuatan kain batik tulis sebagai bagian dari ciri khas Kabupaten Magetan yang dikerjakan oleh masyarakat asli kota Magetan. Batik Magetan mengusung berbagai motif, seperti motif cucak rowo, pring temu rose, parang rusak dan motif pring sedapur. Motif batik pring sedapur merupakan motif batik dari Kabupaten Magetan yang paling terkenal. Sejak tahun 2006 batik pring sedapur dijadikan seragam batik bagi Pegawai Negeri Sipil (PNS) di lingkungan Pemerintah Kabupaten Magetan.

Batik pring menjadi ciri khas batik Kabupaten Magetan. Motif batikpring menggunakan motif bambu yang biasa dalam bahasa Jawa diistilahkan dengan sebutan pring. Motif batik pring dijadikan ciri khas Kabupaten Magetan yang melambangkan kerukunan dan kebersamaan. Pemilihanmotif batik pring terinspirasi banyaknya tumbuhan bambu yang mengelilingi daerah Papringan, Desa Sidomukti, Plaosan, Magetan. Desa Sidomukti sebagai salah satu desa yang menghasilkan batik di Kabupaten Magetan dan ditetapkan sebagai tempat wisata kampung batik.Selain Desa Sidomukti, terdapat beberapa desa lain di Kabupaten Magetan yang didoronguntuk mengembangkan industri batik, salah satunya yaitu di Desa Kediren. Desa Kediren merupakan salah satu desa yang terletak di Kecamatan Lembeyan, Kabupaten Magetan. Banyak sawah terbentang luas di Desa Kediren. Hal ini didukung dengan letak geografis yang berdekatan dengan Gunung Lawu. Desa Kediren sangat terkenal dengan hasil sawah berupa tanaman jagung. Tanaman jagung menjadi keunggulan Desa Kediren, bahkan menjadi ciri khas daerah tersebut.

Sejak bulan Desember 2018 Desa Kediren mengembangkan industri pembuatan batik tulis. Industri tersebut digalakkan dalam rangka meningkatkan kreatifitas dan perekonomian desa. Industri batik di Desa Kediren telah menerima beberapa pesanan. Meski sudah menerima pesanan, ternyata para pengrajin batik tulis Desa Kediren baru sekali mendapatkan pelatihan pembuatan batik. Kurangnya pelatihan menyebabkan munculnya masalah dalam proses pembuatan batik, seperti kurang sesuainya warna batik yang diinginkan dengan warna batik yang dihasilkan. Hal ini menjadikan para pengrajin merasa kurang puas dengan batik yang dihasilkan. Industri batik Desa Kediren memiliki keinginan untuk meningkatkan kualitas batik tulis yang dihasilkannya.Desa Kediren ingin menjadikan batiknya memiliki ciri khas yang menjadi kebanggaan warga desa. Terinspirasi tanaman jagung yang tampak 


\section{Indonesian Engagement Journal}

Vol. 2 No. 1 Juni 2021

terhampar di lahan pertanian, maka aparat Desa dan masyarakat berkeinginan menjadikan motif jagung sebagai motif batik tulis mereka sebagai simbol kebanggaan Desa Kediren.

Meski sudah berjalan enam bulan, akan tetapi industri batik tulis motif jagung di Desa Kediren belum berjalan baik. Hal tersebut dikarenakan keterbatasan Sumber Daya Manusia (SDM) yang memiliki kemampuan membuat batik. Diperlukan upaya untuk meningkatkan kemampuan warga Desa Kediren dalam membuat batik tulis yang lebih baik lagi. Hal ini mendorong tim pengabdian kepada masyarakat untuk mengadakan kegiatan pengabdian kepada masyarakat yang berjudul "Pelatihan Membuat Batik Tulis Motif Jagung Guna Meningkatkan Life Skills Warga Kediren Magetan."

\section{METODE}

Pengabdian kepada masyarakat ini menggunakan metode Asset Based Communities Development (ABCD). Metode ini berupaya meningkatkan kapasitas masyarakat agar mampu mengenali dan memanfaatkan segala kekuatan dan asset yang dimiliki. Tim pengabdian masyarakat mengutamakan pemanfaataan aset dan potensi yang dimiliki masyarakat guna lebih memberdayakan mereka (Mahmudah \& Supiah: 2018). Pelatihan dengan praktik membuat batik tulis motif jagung menjadi program utama dalam pengabdian masyarakat ini. Pelatihan dilaksanakan bagi warga dengan fasilitator salah satu warga yang sudah lebih kompeten dalam membuat batik tulis motif jagung. Pendekatan kualitatif deskriptif digunakan untuk mendeskripsikan pelaksanaan pelatihan membuat batik tulis motif jagung guna meningkatkan life skills warga Desa Kediren Kabupaten Magetan. Pendekatan kualitatif deskriptif yaitu suatu pendekatan untuk menggambarkan suatu variabel yang berkenaan dengan masalah yang diteliti tanpa mempersoalkan hubungan antar variabel. ${ }^{12}$

Kegiatan diawali dengan melakukan analisis kebutuhan pelatihan dengan melakukan observasi keadaan lingkungan desa dan wawancara dengan warga desa, perangkat desa dan tokoh masyarakat. Setelah melakukan analisa kebutuhan dilanjutkan dengan pelaksanaan pelatihan yang terdiri dari tiga tahap yaitu tahap

${ }^{12}$ Faisal, S., Format-format Penelitian Sosial (Jakarta: Rajawali Press, 1992), 90. 


\section{Indonesian Engagement Journal}

Vol. 2 No. 1 Juni 2021

persiapan, tahap pelaksanaan dan tahap evaluasi. Dalam tahap persiapan kegiatannya mencakup wawancara lapangan dan konsultasi, membentuk panitia pelaksana kegiatan, mencari narasumber, menentukan lokasi pelatihan, koordinasi dengan aparat danibu-ibu pengrajin batik tulis Desa Kediren. Tahap pelaksanaan merupakan tahap melatih secara langsungpesertapelatihantentang cara pembuatan batik tulis bermotif jagung. Peserta pelatihan terdiri dari para ibu yang berjumlah 20 orang. Tahap terakhir dari kegiatan yaitu evaluasi melalui tanya jawab tim pengabdian dengan peserta pelatihan dalam menciptakan produk batik tulis bermotif jagung yang berkualitas. Hasil yang diharapkan dari kegiatan pelatihan ini yaitu meningkatnya life skills peserta dalam membuat batik tulis motif jagung.

\section{ANALISIS DAN PEMBAHASAN}

Ide kegiatan pelatihan membuat batik tulis motif jagung guna meningkatkan life skills warga Desa Kediren Kabupaten Magetan diperoleh melalui analisis kebutuhan yang dilakukan melalui observasi dan wawancara di lingkungan Desa Kediren. Saat observasi didapatkan data bahwa mayoritas lahan warga Desa Kediren ditanami jagung seperti dalam gambar 1. Setiap musim kemarau Desa Kediren mengalami kekeringan. Di musim kemarau para petani merasakan kesulitan untuk menanam padi. Selama ini para petani lebih memilih menanam jagung, ketela, dan tanaman lainnya yang dapat bertahan hidup di musim kemarau.

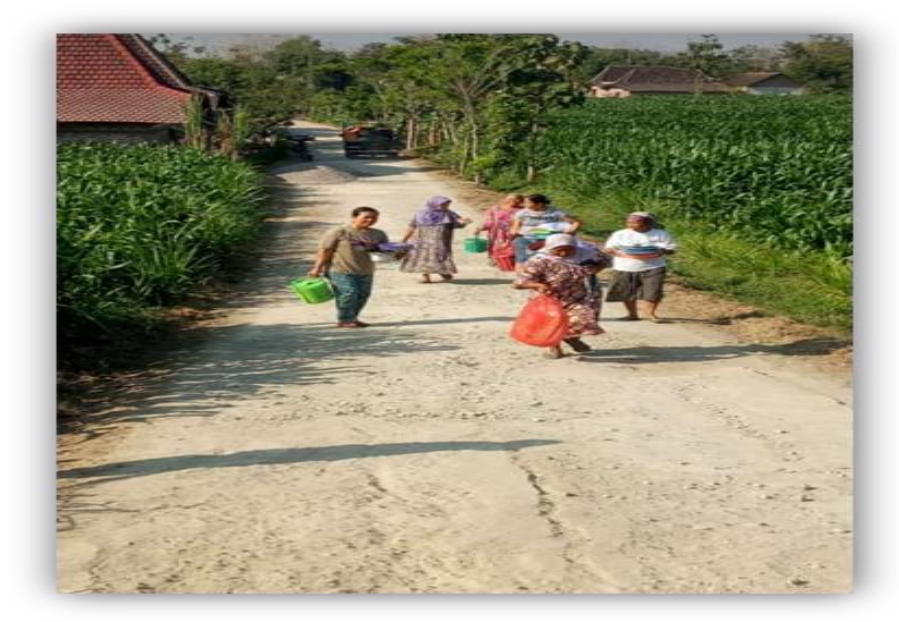

Gambar 1. Lahan petani yang ditanami jagung 


\section{Indonesian Engagement Journal}

\section{Vol. 2 No. 1 Juni 2021}

Data observasi yang diperoleh didukung dengan hasil wawancara dengan perangkat Desa Kediren. Perangkat Desa Kediren menyampaikan bahwa jagung memang menjadi tanaman unggulan wilayah tersebut. Selain itu perangkat Desa Kediren juga menyampaikan banyak generasi muda dan wanita yang memilih bekerja sebagai Tenaga kerja Wanita (TKW) keluar negeri. Agar tidak semakin banyak warga desa yang meninggalkan Desa Kediren, maka perangkat desa berusaha meningkatkan perekonomian warga desa. Salah satu cara untuk meningkatkan perekonomian yaitu dengan mengembangkan industri batik tulis sejak Desember 2018. Industri batik tulis diharapkan dapat memberikan pemasukan tambahan bagi warga desa.

Industri batik tulis menjadi potensi Desa Kediren yang ingin dikembangkan secara serius. Perangkat Desa menyampaikan masih perlunya pelatihan bagi warga pengrajin batik, dikarenakan selama ini kualitas warna batik yang dihasilkan belum sesuai dengan yang diharapkan. Pihak desa berkeinginan menjadikan batik tulis Desa Kediren semakin baik kualitasnya, bahkan menginginkan motif batik tulis yang dihasikan menunjukkan simbol kebanggaan Desa Kediren yaitu motif jagung. Dari analisis kebutuhan melalui observasi dan wawancara, tim pengabdian mengambil kesimpulan warga membutuhkan pelatihan membuat batik tulis motif jagung guna meningkatkan life skill dalam membuat batik tulis motif jagung.

Kegiatan pelatihan membuat batik tulis motif jagung guna meningkatkan life skills warga Desa Kediren Kabupaten Magetan dilaksanakanpada hari Kamis tanggal 8 Agustus 2019 yang dimulai sejak pukul 08.00 sampai 14.30 WIB. Pelatihan bertempat di area kediamansalah satu warga yaitu rumah Ibu Sunarsih. Adapun sebagai fasilitator yaitu Ibu Hartini. Beliau adalah salah satu penggrajin batik yang kompeten dalam membuat batik tulis. Para ibu anggota PKK dan tim pengabdian masyarakat membantu berjalannya pelatihan ini.

Dalam pembukaan kegiatan pelatihan perangkat Desa Kediren memberikan penjelasan tentang latar belakang maksud dan tujuan diadakannya pelatihan. Selanjutnya disampaikan peluang industri batik tulis dalam rangka meningkatkan ekonomi keluarga.Semua peserta mendengarkan penjelasan dengan seksama dan serius. Dikarenakan para peserta sudah cukup memiliki pengetahuan tentang batik tulis, maka pelatihan lebih difokuskan pada kegiatan praktik membuat batik tulis 


\section{Indonesian Engagement Journal}

Vol. 2 No. 1 Juni 2021

sesuai dengan tujuan pelatihan yaitu meningkatnya kemampuan peserta dalam membuat batik tulis motif jagung.

Di awal fasilitator menyampaikan alat-alat dan bahan yang diperlukan dalam membuat batik tulis. Selanjutnya fasilitator menjelaskan proses pembuatan batik tulis motif jagung yang terdiri dari tujuh tahap, yaitu: (1) Menggambar pola batik atau desain batik gambar jagung. Mulai dari gambar jagung yang masih berbunga, kuncup sampai jagung yang sudah berbiji. Pola batik dibuat dengan cara menjiplak, yaitu meletakkan kain mori sebagai media menggambar pola di atas gambar jagung, dan kemudian menjiplaknya, (2) Mencanting pola atau motif yang sudah digambar, (3) Mewarnai motif pola dengan menggunakan zat pewarna. Selanjutnya setelah pewarnaan, kain dijemur sampai kering kemudian menebali pola dengan menggunakan lilin yang sudah dicairkan menggunakan canting, (4) Pewarnaan kain seluruhnya atau biasa disebut blok kain sesuai dengan warna yang diinginkan, (5) Kain yang sudah diblok warna dijemur semu-semu kering lalu dicelupkan ke air mendidih untuk menghilangkan lilin yang menempel, (6) Menjemur kain hingga semu-semu kering lalu dicuci biasa dengan detergen sedikit untuk menghilangkan sisa-sisa residu, dan (7) Menjemur kain sampai kering, dan jadilah sebuah kain batik.

Peserta mempraktikan secara langsung semua tahapan yang dijelaskan oleh fasilitator. Mereka mengikuti praktik membuat batik tulis motif jagung dengan semangat. Sambil membuat batik, peserta yang berjumlah 20 orang tampak bercanda, bersenda gurau diantara mereka. Candaan dan gurauan selama membuat batik tulis menjadikan suasana semakin akrab dan menyenangkan. Kegitan pelatihan dilaksanakan di dalam rumah dan di pelataran rumah. Seluruh kegiatan pelatihan diikuti dengan baik oleh semua peserta. Tampak sebagian besar peserta sudah mampu membuat batik tulis motif jagung. Hal tersebut dapat dilihat dari kemampuan peserta mempraktekan setiap tahapan dalam membuat batik motif jagung. Kegiatan peserta membuat batik tulis motif jagung dapat dilihat pada gambar di bawah ini. 


\section{Indonesian Engagement Journal}

Vol. 2 No. 1 Juni 2021

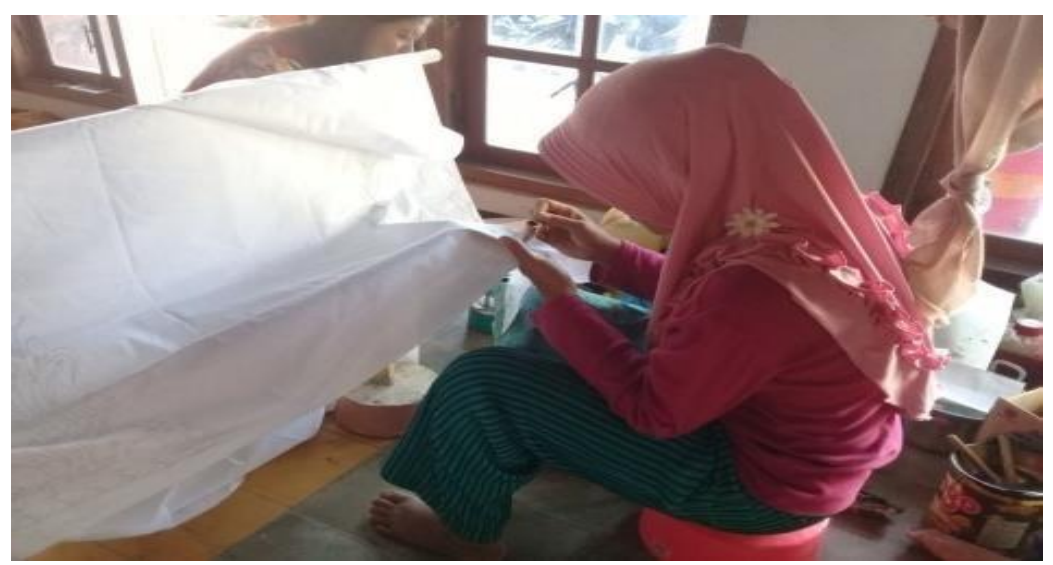

Gambar 2. Proses pembuatan pola batik

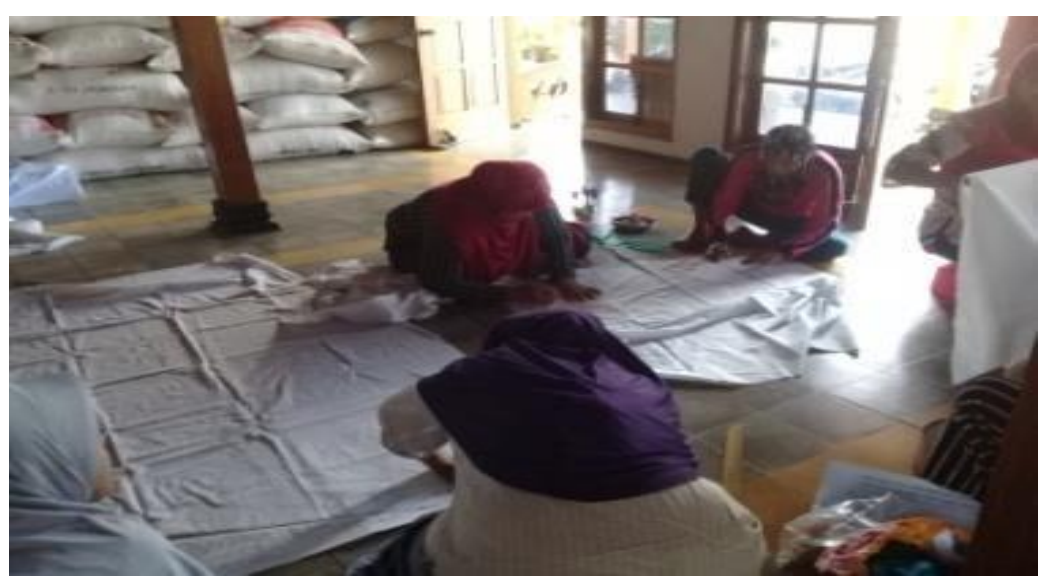

Gambar 3. Proses pencatingan

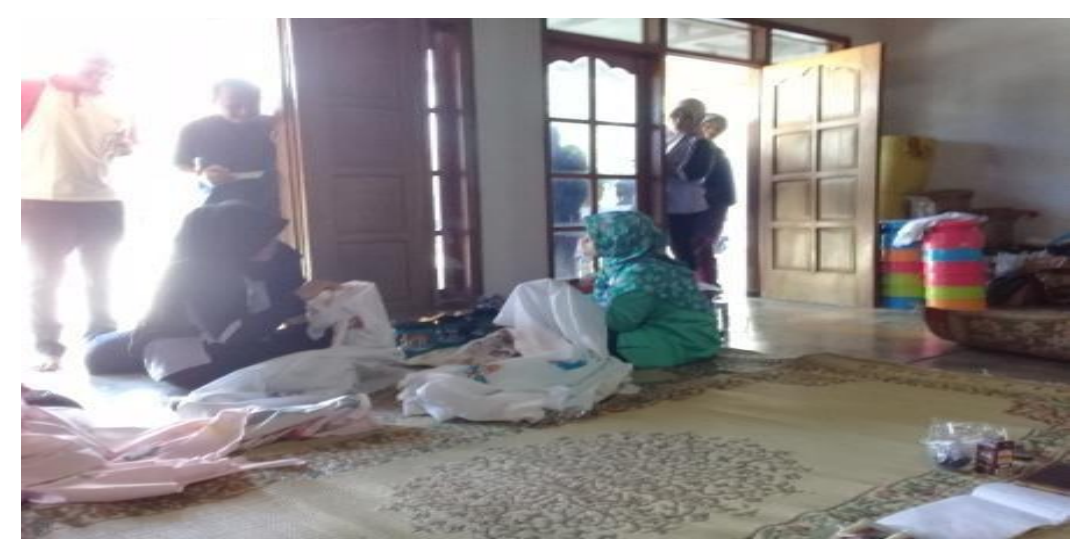

Gambar 4. Proses penebalan pola menggunakan cating 
Indonesian Engagement Journal

Vol. 2 No. 1 Juni 2021
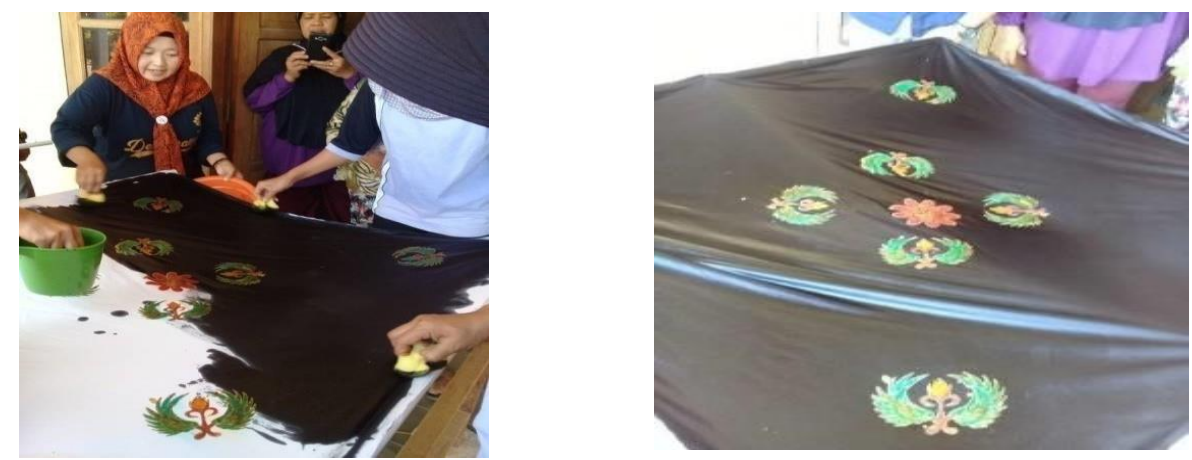

Gambar 5. Proses blok kain yaitu pewarnaan kain seluruhnya

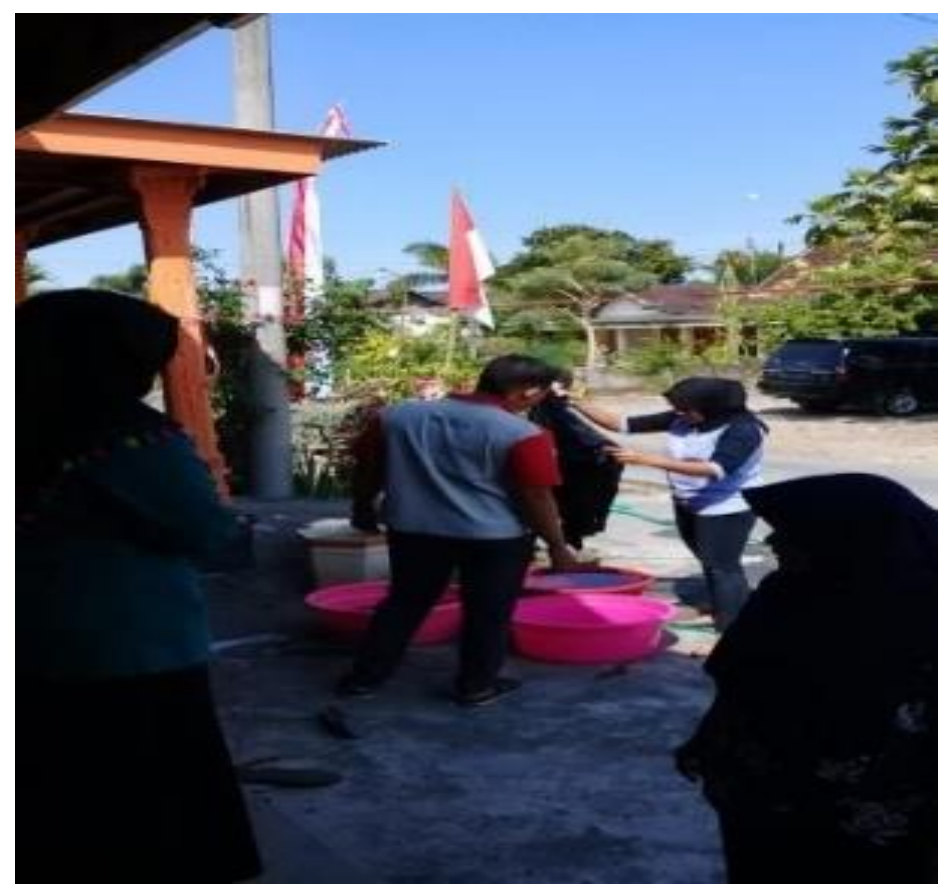

Gambar 6. Proses pencucian kain 


\section{Indonesian Engagement Journal}

Vol. 2 No. 1 Juni 2021

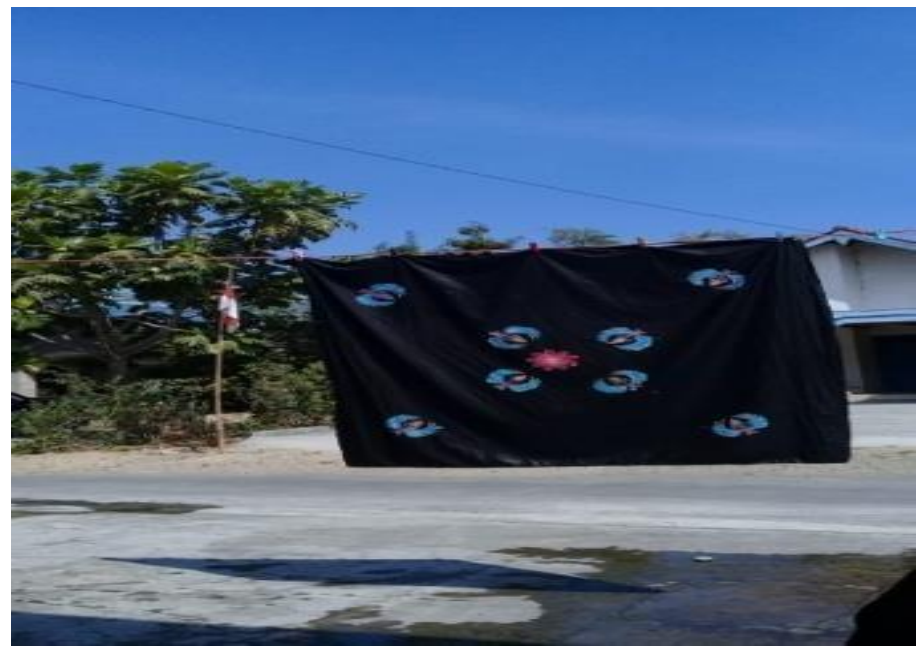

Gambar 7. Proses menjemur kain

Guna mengevaluasi kegiatan pelatihan pembuatan batik tulis motif jagung dilakukan observasi dan wawancara. Berdasarkan obsevasi terlihatpeserta memiliki respon positif terhadap pelatihan membuat batik tulis motif jagung.Peserta menyampaikan kegiatan pelatihan mampu meningkatkan pengetahuan dan keterampilan mereka dalam membuat batik tulis motif jagung. Dengan adanya pelatihan mereka berharap mampu meningkatkan perekonomian warga. Mereka juga berharap kegiatan pelatihan dilaksanakan secara rutin sebulan sekali.

\section{KESIMPULAN}

Kegiatan pengabdian masyarakat berupa Pelatihan Membuat Batik Tulis Motif Jagung Guna Meningkatkan Life Skills Warga Kediren Magetan sangat bermanfaat bagi peserta, karena memberikan pelatihan dengan praktik secara langsung membuat batik tulis motif jagung. Pelatihan ini mampu meningkatkan life skills membuat batik tulis motif jagung sebagai ikon kebanggaan Desa Kediren Kabupaten Magetan. Pelatihan yang dilaksanakan diharapkan mampu membekali masyarakat dengan keterampilan membatik sebagai mata pencaharian tambahan selain bertani menanam jagung di sawah. Sebaiknya kegiatan ini rutin dilaksanakan dan melibatkan lebih banyak warga masyarakat. 


\section{Indonesian Engagement Journal}

Vol. 2 No. 1 Juni 2021

\section{DAFTAR PUSTAKA}

Faisal, S., (1992), Format-format Penelitian Sosial. Jakarta: Rajawali Press.

Indrati, A.dkk., (2011), "Pengembangan Dokumentasi Elektronik Batik Jawa, Bali dan Madura Berbasis Web," laporan penelitian, Jakarta: Universitas Gunadarma,

Kusrianto, A., (2014), Batik, Filosofi, dan Kegunaan. Yogyakarta: Penerbit Andi.

Mahmudah, N \& Supiah., (2018), "Pemberdayaan pada Anak-anak Gang Dolly di SMA Artantika Surabaya dengan Metode Asset Based Community Development," Jurnal Madani , Vol 1 no 1,

Margaria (2019), "Jenis-jenis batik menurut cara pembuatannya," http://margaria.co.id., akses 1 Oktober 2019

Nurainun (2010), “Analisis Industri Batik di Indonesia,” Jurnal Fokus Ekonomi.

Sari, I.P.dkk., (2018), "HKI pada Batik Tulis Indonesia (Studi Kasus Batik Tulis Tanjung Bumi, Madura)," Jurnal Ekonomi Pendidikan dan Kewirausabaan Unesa, (2018).

Singgih, (2016), "Karakteristik Motif Batik Kendal Interpretasi dari Wilayah dan Letak Geografis," Jurnal Imajinasi.

Siregar, A.P.dkk., (2020), "Upaya Pengembangan Industri Batik Di Indonesia: Dinamika Kerajinan dan Batik," Majalab Ilmiah Vol 37 No.1.

Suliyanto, Novandari, W., \& Setyawati, S.M., (2015), Persepsi Generasi Muda Terhadap Profesi,

Utami, A.D., \& Triyono, R.A., (2011), "Pemanfaatan Blackberry Sebagai Sarana Komunikasi dan Penjualan Batik Online dengan Sistem Dropship di Batik Solo 85," Jurnal Speed_Sentra Penelitian Engineering Dan Edukasi, https://doi.org/10.3112/speed.v4i4.1099.

Wahono. Dkk., (2004), Ragam Hias Batik (Tinjauan Makna dan Simbol), Semarang: Pemerintah Daerah Propinsi Jawa Tengah, Dinas Pendidikan dan Kebudayaan Museum Jawa Tengah "Ronggowarsito",

Wulandari, (2011), Batik Nusantara Makna Filosofis, Cara Pembuatan dan Industri Batik. Yogyakarta: Andi OFFSET. 